\title{
Diurnal and seasonal $h s p 70$ gene expression in a cryptic reef fish, the bluebanded goby Lythrypnus dalli (Gilbert 1890)
}

\author{
Expresión diurna y estacional del gen hsp70 en un pez críptico arrecifal, el gobio azul rayado \\ Lythrypnus dalli (Gilbert 1890)
}

\begin{abstract}
Priscila Conde-Guerrero', Tania Zenteno-Savín, Crisalejandra Rivera-Pérez², Fausto Valenzuela-Quiñonez , Juan Antonio De Anda-Montañez ${ }^{1}$

1 Centro de Investigaciones Biológicas del Noroeste, S.C. Instituto Politécnico Nacional 195, Col. Playa Palo de Santa Rita Sur; La Paz, BCS 23096, México.

2 CONACYT-Centro de Investigaciones Biológicas del Noroeste, S.C. Instituto Politécnico Nacional 195, Col. Playa Palo de Santa Rita Sur; La Paz, BCS 23096, México.
\end{abstract}

\section{ABSTRACT}

Physiological responses of marine organisms are influenced by environmental variations, particularly in dynamic habitats. These variations could be at a diel or seasonal scale, and requires acclimation responses that, at a molecular level, are facilitated by gene expression regulation. Circadian rhythms allow organisms to adjust to recurring environmental changes and to synchronize physiological processes. Increased Hsp70 gene expression allows organisms to protect themselves against heat and other stressors, conferring them a periodically changing thermotolerance. This study aimed at analyzing whether the variability of exogenous factors (temperature, dissolved oxygen, salinity) in diurnal or seasonal scales affects hsp70 expression in cryptic reef fishes in their natural environment. The study model was Lythrypnus dalli, an endemic cryptic reef fish inhabiting shallow waters throughout the Gulf of California. Physical parameters varied seasonally; temperature increased $6^{\circ} \mathrm{C}$ during the warm season, salinity and dissolved oxygen remained with minor variation. Minimal changes in temperature $\left( \pm 1^{\circ} \mathrm{C}\right)$ occurred diurnally. Expression levels of $h s p 70$ increased significantly during the warm season $(p<0.05)$, perhaps related to seasonal thermal changes. No difference in $h s p 70$ was observed during the diurnal cycle $(p>0.05)$. L. dalli has apparently developed phenotypic plasticity to face environmental variability at diurnal and seasonal scales.

Key words: circadian rhythm, cryptic reef fish, heat shock protein 70, Lythrypnus dalli, temperature.

\section{RESUMEN}

Las respuestas fisiológicas de los organismos marinos son influenciadas por variaciones ambientales, particularmente en hábitats dinámicos. Éstas pueden ser a escala diurna o estacional y requieren respuestas que, a nivel molecular, son facilitadas por inducción de expresión génica. Los ritmos circadianos permiten ajustar cambios ambientales recurrentes y sincronizarlos con procesos fisiológicos. El incremento en la expresión de $h s p 70$ es una estrategia para enfrentar cambios térmicos y otros estresores, confiriendo termotolerancia que cambia periódicamente. El objetivo de este estudio fue analizar si la variabilidad de factores exógenos (temperatura, oxígeno disuelto, salinidad) en escalas diurna

*Autor para correspondencia:Tania Zenteno Savín

Correo electrónico: tzenteno04@cibnor.mx

Recibido: 3 de diciembre de 2020

Aceptado: 2 de febrero de 2021 o estacional afecta la expresión de $h s p 70$ en peces crípticos en su medio natural. El modelo de estudio fue Lythrypnus daIli, un pez críptico arrecifal que habita el Golfo de California. Los parámetros físicos variaron estacionalmente; la temperatura aumentó $6^{\circ} \mathrm{C}$ durante la temporada cálida, salinidad y oxígeno disuelto permanecieron con variaciones mínimas. Se observaron cambios mínimos $\left( \pm 1^{\circ} \mathrm{C}\right)$ en temperatura en el ciclo diurno. Los niveles de expresión de hsp70 aumentaron durante la estación cálida $(p<0.05)$. No se observaron diferencias en hsp70 durante el ciclo diurno $(p>0,05)$. L. dalli aparentemente ha desarrollado plasticidad fenotípica para enfrentar la variabilidad ambiental diurna y estacional.

Palabras clave: ritmo circadiano, pez críptico arrecifal, proteína choque térmico 70, Lythrypnus dalli, temperatura.

\section{INTRODUCTION}

Environmental variability in the marine environment plays an important role in the distribution of species and could be a promoter of biodiversity, since it gives rise to genetic and phenotypic variations (Culumber et al., 2012)This variability can occur drastically throughout a diel cycle due to the influence of tide, rainfall or primary productivity (Kwiatkowski et al., 2016)lowering seawater aragonite (CaCO3. In addition, the seasonal variation is also significant and temperature is one of the factors with evident seasonal fluctuation due to the annual cycle of solar radiation, and is closely related to other abiotic factors (Gunderson et al., 2016).

Marine organisms adapt to the environmental changes that prevail in their natural habitat. These variations require specific and rapid responses in some molecular pathways associated with acclimatization responses; modulation of gene expression is one of these first responses (Tine, 2017). Circadian rhythms are biological cycles with a duration close to a 24-hour period that persist even in the absence of external stimuli, involving oscillations in gene expression and the consequent modulation of various physiological processes (Podrabsky, 2004). Circadian rhythms are an important adaptive trait, since they allow a concordance between environmental events and the organization of biological functions, preparing organisms to respond to predictable environmental conditions (Vera et al., 2013). 
Climate change could have a significant impact on survival strategies in marine organisms. Thus, the adaptive responses of organisms to their current conditions can provide important clues about how they might face future environmental changes (Habary et al., 2016). A large number of studies analyzing the molecular response to fluctuating environmental conditions have been conducted under controlled laboratory conditions. However, in the natural environment this response is affected by the synergistic action of different environmental parameters and is less known. Therefore, it is important to expand knowledge about the expression and regulation of genes related to individual physical condition to better understand the adaptive processes of wild populations (Evans and Hofmann, 2012).

Studies that analyze the effect of environmental variability on the molecular response of marine organisms have focused on the expression of heat shock proteins (HSPs) (Tomanek, 2010). These proteins act as chaperones and contribute to the stabilization of denatured polypeptides preventing their aggregation during stressful conditions. The HSP70 family has been well studied because it is highly conserved and has been found in a wide variety of organisms (Madeira et al., 2012; Yamashita et al., 2010).

Fishes, particularly reef fishes, are a potential model for studying these responses, as they are organisms whose physiology is closely linked to the environment. Tropical reefs are coastal areas influenced by a convergence between ocean and land variability, making them appropriate systems for studying temporal and spatial fluctuations in physical parameters and their effects on the organisms inhabiting them. Furthermore, rocky reefs can host a great diversity of fish species, from which a large proportion could be composed of cryptic species (Brandl et al., 2018).

The aim of this study was to evaluate the effect of the variation in environmental factors, such as temperature, dissolved oxygen, and salinity, at diurnal and seasonal scale on the expression of $h s p 70$ gene in cryptic reef fish. The bluebanded goby Lythrypnus dalli (Gilbert, 1890) was chosen as the model species due to its high site fidelity and preference for shallow waters. These traits allow to analyze the physiological responses to fluctuating conditions of its natural environment. To achieve this, we quantified the expression of a stress related gene ( $h s p 70$ ) during a 24-hour period, both during warm and cold seasons, in order to contrast the responses to extreme environmental conditions.

\section{MATERIALS AND METHODS \\ Field sampling}

Specimens of $L$. dalli were collected during a diel cycle in a warm (October 2017) and a cold (April 2018) season in a rocky shore named Punta Diablo in Bahía La Paz, Baja California Sur, Mexico (24 18' 45" N, 110²0'13" W). Sample collection was performed by SCUBA diving every $4 \mathrm{~h}$ over each 24-hour period in both seasons. A total of 6 dives per day were performed at $12 \mathrm{~m}$ depth, during $20 \mathrm{~min}$ approximately and started at 12:00 hr. During each dive, an ethanol- clove oil solution was spread over holes and crevices found in the sampling rocky wall. Anesthetized individuals were caught with nets and taken to the surface, where they were immediately frozen in liquid nitrogen. Physical parameters (temperature, dissolved oxygen and salinity) were measured in situ every hour to determine 24-hour changes. All parameters were measured at the same time using a multiparameter probe (YSI Pro 2030, OH, USA). The sensor was submerged $10 \mathrm{~m}$ depth from the surface, as closely as possible to the sampling area.

\section{RNA isolation and CDNA synthesis}

Five individuals for each hour of sampling were considered for quantification of the target transcripts ( 5 biological replicates), for both seasons. It was not possible to capture organisms in all the sampling hours in October. Thereby, total RNA was extracted from 47 individuals ( 100 mg) according to the acid guanidinium thiocyanate-phenol-chloroform method of Chomczynski and Sacchi (1987). Since these fishes have small body size $(<3 \mathrm{~cm})$, the whole fish was used for RNA extraction. DNA present in samples was removed by Turbo DNAse treatment (TURBO DNA-free ${ }^{\mathrm{TM}}$ Kit, Invitrogen). RNA concentration in samples was assessed by measuring the absorption at 260 and $280 \mathrm{~nm}$ using a Nanodrop ND-2000 spectrophotometer (Thermo Scientific); an absorption ratio of 1.8-2.1 indicated pure RNA samples. The RNA integrity was evaluated by $1 \%$ agarose gel electrophoresis; presence of $18 \mathrm{~S}$ and $28 \mathrm{~S}$ rRNA bands confirm RNA quality. Complementary DNA (cDNA) was synthetized using one microgram of RNA and ImProm-II ${ }^{\text {TM }}$ Reverse Transcriptase (Promega) according to the instructions provided by the manufacturer and stored at $-20{ }^{\circ} \mathrm{C}$.

\section{Primers design}

Specific forward and reverse primers for both hsp70 and the reference gene $\beta$-actin were designed ( $150 \mathrm{bp}$ amplicon length, $55 \% \mathrm{GC}$ content, $60{ }^{\circ} \mathrm{C}$ primer $\mathrm{T}_{\mathrm{m}}$ ) using Primer3v.0.4.0 (Untergasser et al., 2012). $\beta$-actin is one of the most commonly used reference gene to quantify mRNA and its stability has been analyzed in some fish species under thermal stress conditions (Ma et al., 2019; Nascimento et al., 2016; Purohit et al., 2015). The primers were F: 5-GAGAACGTGCAGGACCTGCT-3， R: 5-CCGGGCTGGTTGTCGAAGTA-3 for hsp70; and F: 5-TGAAGATCCTGACAGAGCGTGGC-3, R: 5- TTGCCGATGGTGATGACCTGT -3 for $\beta$-actin. For each gene, primers were designed from the alignment of homologous sequences of phylogenetically related fish, which were found in the NCBI database.

A polymerase chain reaction (PCR) was carried out to confirm primer amplification size. In a $12.5 \mu \mathrm{L}$ reaction, the PCR was performed using $1 \mu \mathrm{L}$ of template CDNA (50 $\mathrm{ng} \mathrm{LL}^{-1}$ ), $1 \mu \mathrm{L}$ of forward and reverse primer $(5 \mu \mathrm{M})$ each, $6.25 \mu \mathrm{L}$ of GoTaq $^{\circ}$ DNA polymerase $2 X$ (Promega) and $3.25 \mu \mathrm{L}$ of Milli- ${ }^{\circ}$ sterile water. Cycling parameters for PCR were as follows: 95 ${ }^{\circ} \mathrm{C}$ for $5 \mathrm{~min}$; 40 cycles of $94^{\circ} \mathrm{C}$ for $1 \mathrm{~min}, 50-60{ }^{\circ} \mathrm{C}$ for $1 \mathrm{~min}$, then $72{ }^{\circ} \mathrm{C}$ for $1 \mathrm{~min}$; and $72^{\circ} \mathrm{C}$ for $10 \mathrm{~min}$. PCR products were 
separated on $1 \%$ TBE agarose/Synergel ${ }^{\circ}$ gels and visualized using Uview on a UV transluminator (Chemi-Doc). The resulting amplicons were sequenced, and the identities of the genes were confirmed by BLAST searches.

\section{qPCR analysis}

Real time PCRs (qPCR) were done to amplify and measure $h s p 70$ gene expression. The specific primers used to amplify $h s p 70$ and the reference gene $\beta$-actin were the same previously used for the conventional PCR. In a $15 \mu \mathrm{L}$ reaction, the PCR was performed using $5 \mu \mathrm{L}$ of template $\left(5 \mathrm{ng} \mathrm{\mu L}^{-1}\right.$ of cDNA), $1.5 \mu \mathrm{L}$ of buffer $10 \mathrm{X}, 0.75 \mu \mathrm{L}$ of $\mathrm{MgCl}_{2}(50 \mathrm{mM}), 0.25$ $\mu \mathrm{L}$ of dNTPS $(10 \mathrm{mM}), 0.7 \mu \mathrm{L}$ of forward and reverse primer $(5 \mu \mathrm{M})$ each, $0.07 \mu \mathrm{L}$ of recombinant Taq polymerase $\left(5 \mathrm{U} \mu \mathrm{L}^{-}\right.$ 1), $0.75 \mu \mathrm{L}$ of Eva Green 20X (Biotium) and $5.8 \mu \mathrm{L}$ of Milli-Q sterile water. Cycling parameters for qPCR were as follows: 95 ${ }^{\circ} \mathrm{C}$ for $10 \mathrm{~min} ; 40$ cycles of $95^{\circ} \mathrm{C}$ for $15 \mathrm{~s}, 60^{\circ} \mathrm{C}$ for $1 \mathrm{~min}$, then $72^{\circ} \mathrm{C}$ for $20 \mathrm{~s}$; and $72^{\circ} \mathrm{C}$ for $10 \mathrm{~min}$; and melt curve from $65^{\circ} \mathrm{C}$ to $95^{\circ} \mathrm{C}$, at $0.5^{\circ} \mathrm{C}$ for $10 \mathrm{~s}$. All samples were run in triplicate. No-template controls (NTCs) were included to ensure the lack of contamination. Amplification efficiencies of the primers were verified by doing standard curves for both genes (Table 1). Furthermore, melting curves were analyzed to verify $P C R$ specificity. The relative expression levels of $h s p 70$ was measured against $\beta$-actin (reference gene) and was calculated according to the method of Pfaffl (2001).

\section{Statistical analysis}

Statistical differences in $h s p 70$ gene expression between different hours of sampling and seasons were analyzed using STATISTICA v10 (STATISTICA ${ }^{\circ}$, v10, StatSoft, Inc., Tulsa, OK, USA). The assumptions of normality (Shapiro-Wilk) and homogeneity of variances (Levene's test) were tested. Because neither assumption was met, statistical differences were analyzed by a non-parametric analysis (Kruskall-Wallis). All differences were considered significant at $p<0.05$.

\section{RESULTS}

A total of 62 specimens of $L$. dalli $(\mathrm{n}=62$ individuals, $\mathrm{Lt}$ $($ mean $\pm S D)=2.3 \pm 0.38 \mathrm{~cm} ; \mathrm{Wt}($ mean $\pm S D)=123.98 \pm 53.24$ $\mathrm{mg}$ ) were collected during the sampling periods. In October 2017, a total of 25 individuals were obtained; however, this species was not found in all sampling hours (Figure 1). In April 2018, 37 individuals were obtained in all sampling hours.

\section{Environmental data}

Temperature, salinity and dissolved oxygen measurements are shown in Figure 2. Averaged water temperature

Table 1. Efficiency analysis for the target gene ( $h s p 70)$ and the reference gene ( $\beta$-actin)

Tabla 1. Análisis de eficiencia para el gen de interés ( $h s p 70$ ) y el gen de referencia ( $\beta$-actin).

\begin{tabular}{lcccc}
\hline Gene & Slove & $\mathbf{R}^{\mathbf{2}}$ & Efficiency & Percent \\
\hline Hsp70 & -2.33 & 0.97 & 2.68 & 168.15 \\
B-actin & -2.68 & 0.99 & 2.36 & 136.00 \\
\hline
\end{tabular}

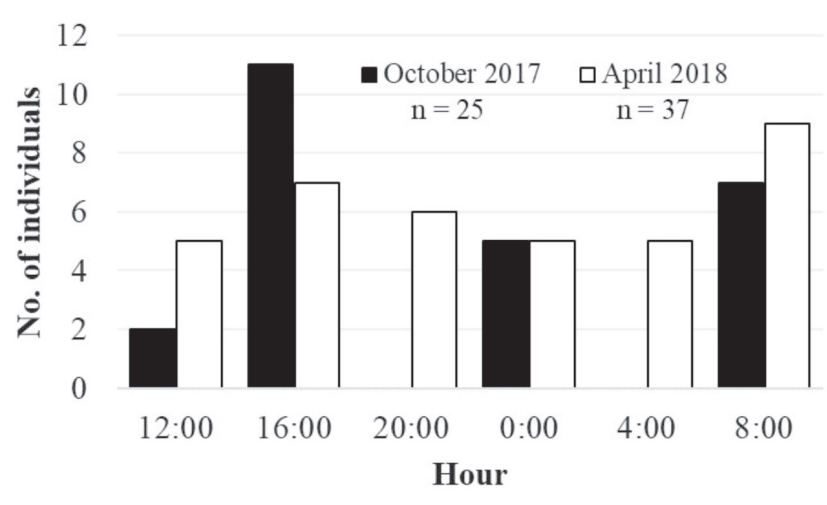

Figure 1. Abundance of Lythrypnus dalli during a diel cycle, in two seasons: warm (October 2017) and cold (April 2018) at Punta Diablo, La Paz, Baja California Sur, Mexico.

Figura 1. Abundancia de Lythrypnus dalli durante el ciclo diurno a diel cycle, en dos estaciones: cálida (Octubre 2017) y fría (Abril 2018) en Punta Diablo, La Paz, Baja California Sur, México.
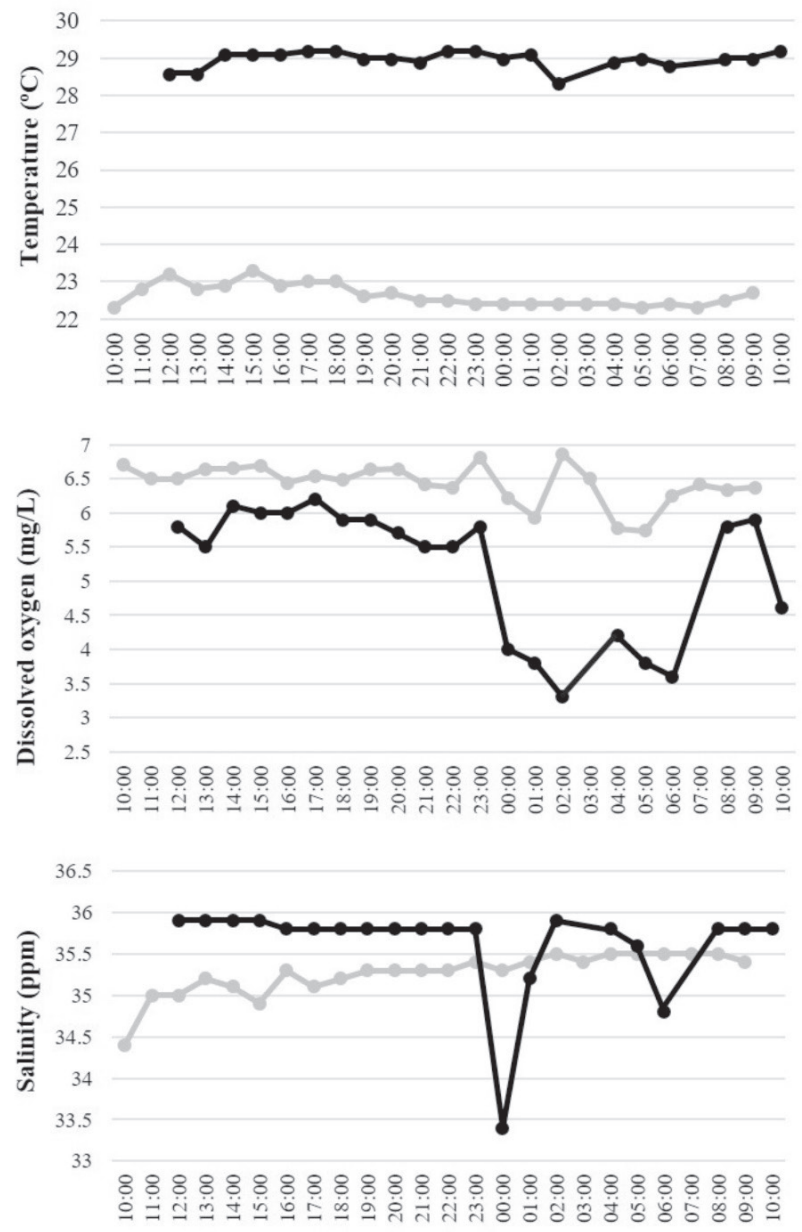

Figure 2. Physical parameters during the sampling diel cycle, in a warm (October 2017; black line) and cold season (April 2018; gray line) at Punta Diablo, La Paz, Baja California Sur, Mexico.

Figura 2. Parámetros físicos a lo largo del día de muestreo en la temporada cálida (Octubre 2017; línea negra) y temporada fría (Abril 2018; línea gris) en Punta Diablo, La Paz, Baja California Sur, México. 
differed by $6.35^{\circ} \mathrm{C}$ between seasons, it was higher in October compared to April, with an average recorded value of 28.98 $\pm 0.23^{\circ} \mathrm{C}$ in October and $22.3 \pm 0.30^{\circ} \mathrm{C}$ in April (cold season). Salinity was lower in October ( $35.62 \pm 0.57 \mathrm{ppt}$ ) than in April (35.26 $\pm 0.26 \mathrm{ppt})$. Dissolved oxygen concentration was higher in April $\left(6.43 \pm 0.29 \mathrm{mg} \mathrm{L}^{-1}\right)$ compared to October (5.19 \pm $\left.0.98 \mathrm{mg} \mathrm{L}^{-1}\right)$.

During the diel cycle, no significant changes were recorded in these parameters in both seasons. Water temperature changed by $1{ }^{\circ} \mathrm{C}$ during a 24-hour period in both seasons, from 28.3 to $29.2^{\circ} \mathrm{C}$ in October (warm season) and 22.3 to $23.3^{\circ} \mathrm{C}$ in April (cold season). Salinity ranged from 33.4 to 35.9 ppt in October, and from 34.9 to 35.5 ppt in April. Dissolved oxygen concentration ranged from 3.3 to $6.2 \mathrm{mg} \mathrm{L}^{-1}$ in October, and from 5.74 to $6.86 \mathrm{mg} \mathrm{L}^{-1}$ in April.

\section{Comparison of hsp70 gene expression between seasons and daytime}

Real time PCR analysis was done using CDNA template generated from 47 organisms. Hsp70 expression level was measured in each individual specimen; however, only 25 samples amplified during the qPCR analysis. The results of the relative $h s p 70$ expression levels were normalized to that of the $\beta$-actin gene and were expressed as the median \pm percentiles ( $25-75 \%$ ). Significant differences between seasons were revealed according to the Kruskal-Wallis test $\left(H_{1,25}=9.9526 ; p=0.0016\right)$. Hsp70 gene expression was higher during October compared to April (Figure 3). The effect of the 24-hour period was also analyzed (Figure 4). No significant differences were observed during the diel cycle in October $\left(H_{3,12}=9.9526 ; p=0.3910\right)$ or April $\left(H_{5,13}=8.6703 ; p=0.1230\right)$.

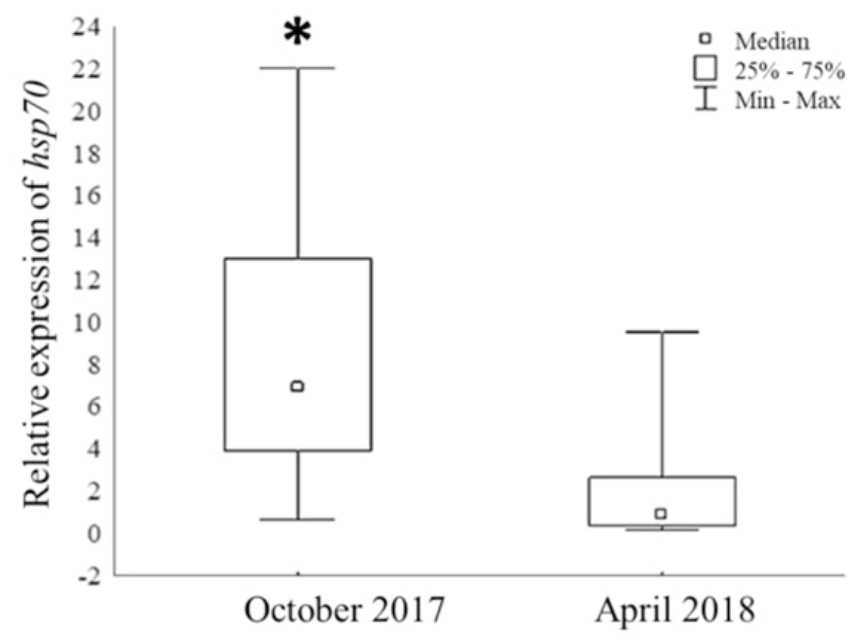

Figure 3. Expression of $h s p 70$ gene between seasons in Lythrypnus dalli samples $(n=25)$ obtained at Punta Diablo, La Paz, Baja California Sur, Mexico. ${ }^{*} p<0.05$.

Figura 3. Análisis de expresión de $h s p 70$ entre estaciones en muestras de Lythrypnus dalli $(\mathrm{n}=25)$ obtenidas en Punta Diablo, La Paz, Baja California Sur, México. ${ }^{*} p<0.05$.
A.

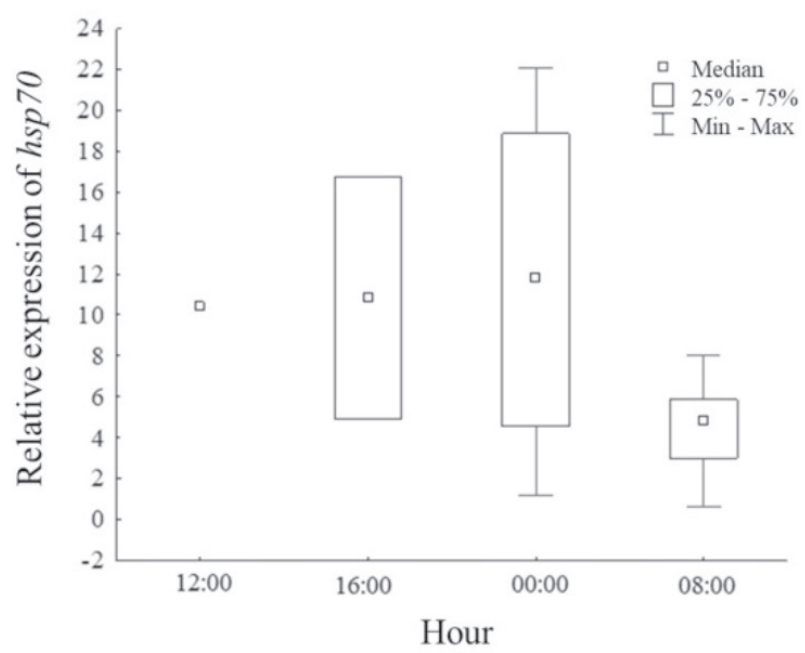

B.

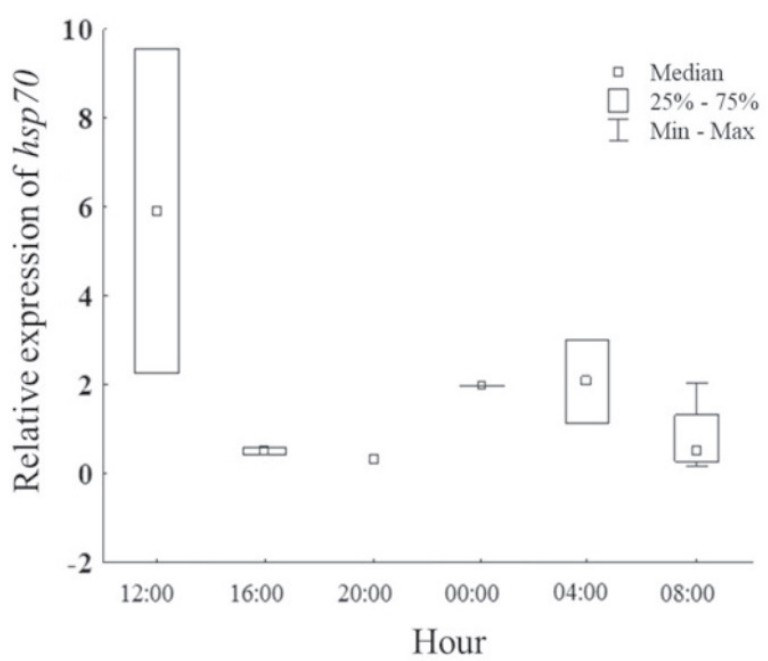

Figure 4. Analysis of $h s p 70$ expression during a 24-hour period in A. warm $(n=13)$ and B. cold season $(n=12)$, in Lythrypnus dalli samples obtained at Punta Diablo, La Paz, Baja California Sur, Mexico. ${ }^{*} p<0.05$.

Figura 4. Análisis de expresión de $h s p 70$ durante un period de 24 horas en $A$. temporada cálida $(n=13)$ y B. temporada fría $(n=12)$, en muestras de Lythrypnus dalli obtenidas en Punta Diablo, La Paz, Baja California Sur, México. ${ }^{*} p<0.05$.

\section{DISCUSSION}

Changes in the $h s p$ genes expression in response to thermal variability, particularly $h s p 70$ has been a widely studied response in several fish species (Lund et al., 2002; Podrabsky, 2004; Heredia-Middleton et al., 2008; Yamashita et al., 2010; Logan and Somero, 2011; Lewis et al., 2016; Tunnah et al., 2017; Hassan et al., 2017). However, information about $h s p 70$ expression in response to thermal changes in the natural environment and the effect that temporality (diel, seasonal) has on the modulation of $h s p 70$ gene expression is scarce.

In the present study, the results showed that $h s p 70$ expression levels in L. dalli was significantly higher during October. It may be possible that $h s p 70$ is up-regulated in response to an increase in temperature during the warm season $(<6$ 
$\left.{ }^{\circ} \mathrm{C}\right)$. Similar results showing a higher $h s p 70$ expression during warm conditions has been previously reported in other fish species; Epinephelus coioides and Sparus aurata from the Suez Canal showed an up-regulation with increased water temperature during the hot season, when temperature increases from 19 to $24^{\circ} \mathrm{C}$ (Guerriero et al., 2018). In Salmo salar, a thermal increase from $20^{\circ} \mathrm{C}$ in spring to $27^{\circ} \mathrm{C}$ in summer induced hsp70 expression (Lund et al., 2002). The positive regulation of $h s p 70$, as observed in L. dalli, may have a cytoprotective role as an acclimatization mechanism that allows organisms to face a seasonal temperature variability. This mechanism is critical for the maintenance of cellular functions, since the $h s p 70$ gene participates in folding thermally damaged proteins and preventing their cytotoxic aggregation (Feder and Hofmann, 1999). The mechanisms involved in detecting thermal changes and the consequent induction of gene expression, are not entirely clear. However, some studies suggest that the regulation of $h s p 70$ expression occurs primarily at the transcriptional level (Silver and Noble, 2012). In contrast, a different seasonal pattern in $h s p 70$ expression was observed in Sparus aurata from the Mediterranean (Feidantsis et al., 2013). In this species, $h s p 70$ expression levels increased in early spring (March) when the lowest water temperatures were recorded $\left(11^{\circ} \mathrm{C}\right)$. Hassan et al. (2017) found no differences in $h s p 70$ expression levels between summer conditions in August $\left(36^{\circ} \mathrm{C}\right)$ and December $\left(14{ }^{\circ} \mathrm{C}\right)$ in Oreochromis niloticus from Kaferelsheik, Egypt. The differences between these results and those reported in the present study suggest that thermal threshold for hsps gene expression depends on the temperature at which the organisms are acclimatized (Dietz, 1994; Buckley and Hofmann, 2002).

The effect of thermal variability may differ between species, and even populations, according to phenotypic tolerance and plasticity derived from acclimatization to the thermal conditions prevailing in their environment (Veilleux et al., 2018). Some organisms that inhabit environments with high thermal variability have a greater capacity to modulate the expression levels of some $h s p s$, including $h s p 70$ (Logan and Somero, 2011; Jesus et al., 2013). In contrast, organisms that inhabit narrower thermal ranges (tropical or polar regions) tend to lack a thermal shock response when exposed to acute thermal changes (Hofmann, 2005; Veilleux et al., 2018). Measurement of physical parameters suggest a marked seasonal variation in Punta Diablo, particularly in temperature. A minimum value of $22.3^{\circ} \mathrm{C}$ was recorded in April and a maximum of $29.2^{\circ} \mathrm{C}$ in October. This variability is similar to that reported by other authors in Bahia de La Paz (Bernal et al., 2001; Martínez-López et al., 2001; Martínez-Flores, 2007) whom, in addition, observed slightly higher temperatures from August to October ( 30 to $31^{\circ} \mathrm{C}$ ), and lower from January to March (21 to $24^{\circ} \mathrm{C}$ ). According to this information, the population of $L$. dalli that inhabits Punta Diablo should be facing a thermal variability within a range of up to $10^{\circ} \mathrm{C}$. It is possible that this population has developed tolerance and plasticity in their thermal response, which is reflected as the modulation of $h s p 70$ expression levels. Further studies are re- quired to determine the relationship between the tolerance threshold temperature of $L$. dalli and the induction of $h s p 70$ gene expression.

In the present study, the variability in salinity at Punta Diablo was minimal (0.36 ppm). Obeso-Nieblas et al. (2004) reported that salinity remained homogeneous throughout the year and between years in Bahía de La Paz. Additionally, the seasonal variability in dissolved oxygen concentration was minimal $\left(1.2 \mathrm{mg} \mathrm{L}^{-1}\right)$. It is evident that the seasonality in the study area is marked by temperature, so this factor is suggested as the main modulator of the molecular response of $L$. dalli. Aquatic organisms are not only exposed to seasonal environmental variability, but also on a diel scale. Nonetheless, the response to these fluctuating conditions compared to constant conditions has been poorly studied. In the present study, no significant differences were observed in $h s p 70$ expression levels during a 24-hour period, in either of the two seasons (cold, warm) studied. The environmental variability to which aquatic organisms are exposed on a diel scale can also induce a response, which will potentially depend on the magnitude of the changes.

Diel fluctuations in Bahia de La Paz sea surface temperature differ according to the time of the year; during cold months temperature changes approximately $1{ }^{\circ} \mathrm{C}$, while during the warm period this variation is up to $2{ }^{\circ} \mathrm{C}$ (Martínez-Flores, 2007). This is similar to what was recorded in the present study, the diel variation in Punta Diablo during the sampling days was around $1{ }^{\circ} \mathrm{C}$ in both seasons. Salinity remained stable; however, dissolved oxygen concentration showed a decrease from 6.2 to $3.3 \mathrm{mg} \mathrm{L}^{-1}$ at 0:00 and 06:00 h, respectively. Hypoxia can occur when the level of dissolved oxygen falls below $2.0 \mathrm{mg} \mathrm{L}^{-1}$ or less (Pollock et al., 2007; Vaquer-Sunyer and Duarte, 2008). The variation in dissolved oxygen concentration observed in the present study may not have been enough to induce a $h s p 70$ response in L. dalli during a 24-hour period. In contrast, diel oscillations have been reported in the expression of $h s p s$ in other marine species. Hsp70 expression has a marked daytime regulation in the anemone Nematostella vectensis, reaching higher expression levels at midnight (Oren et al., 2015). Authors conclude that these organisms have circadian mechanisms that allow a thermal compensation response to changing environmental conditions. This response may enable organisms to prevent a series of physiological functions from changing with temperature. A circadian oscillation in $h s p 70$ and $h s p 90$ expression in the coral Acropora millepora were observed, with higher levels reported during the afternoon (16:00 hours); these pattern was attributed to a potential oxidative stress defense, as a result of the coral symbiotes photosynthesis (Levy et al., 2011). However, previous studies show diurnal oscillations in the expression of $h s p s$ genes, which may depend on the magnitude, duration and type of stressors that organisms experience in their natural habitat. It is unclear if this gene modulation is an anticipated response to constant acute environmental changes; more evidence is necessary to clarify the underlying mechanisms.

Volumen XXIII, Número 2 
Different mechanisms for coping with environmental variability have been analyzed to understand lethal and sublethal stress and the differences in the response capacity between species (Evans and Hofmann, 2012). However, the results suggest that organisms have an optimal physiological response within a limited range in environmental conditions, and thresholds in which physiological performance is compromised. This type of data is important to assess how vulnerable organisms are to climate change and, therefore, useful in the context of conservation (Hoey et al., 2016; Illing and Rummer, 2017).

Tropical oceans are expected to increase their temperature by $\sim 3^{\circ} \mathrm{C}$ by the end of the century, which represents a challenge for all reef organisms, especially those at low latitudes (Rummer et al., 2014). It has been suggested that marine organisms could show three possible responses to the environmental conditions projected for the future. First, they could disperse to better conditions (migration); second, organisms could adapt to new environmental conditions over time through genetic change (adaptation); and third, they could modify their phenotype to the predicted new conditions (phenotypic plasticity) (Evans and Hofmann, 2012; Harborne, 2013). While larger or conspicuous fish may disperse to more favorable conditions, the limited dispersal capacity of cryptic fishes makes them particularly susceptible to these changes (Munday et al., 2017; Brandl et al., 2018). Instead, it is possible that these organisms modulate their phenotype and improve their acclimatization capacity. Since information about the physiological and molecular responses of cryptic fish is scarce, further studies are required to elucidate acclimatization capacity, the mechanisms involved and the tolerance ranges at different time-space scales in this group of fishes.

\section{CONCLUSION}

This study suggests a seasonal pattern in $h s p 70$ gene expression in the cryptic reef fish, L. dalli. Apparently, temperature is the main factor that modulates the $h s p 70$ expression, as this factor showed a marked difference between seasons $\left(\sim 6{ }^{\circ} \mathrm{C}\right)$. As a result, $h s p 70$ expression levels were higher during the warm season when average temperature was $28.98{ }^{\circ} \mathrm{C}$. The minimal variation in physical parameters during the 24-hour period may not be enough to induce a hsp70 response, as there were no differences in this gene's expression during the diel cycle. According to these results, no "trained" circadian pattern in hsp70 expression was observed in L. dalli, as reported for other species. The limited dispersal capacity of this species and the effective molecular response to the marked seasonal variability in its habitat, suggest a possible phenotypic modulation that may allow it to cope with changing environmental conditions. More information about this species' physiological limits would be important for predicting its responses to future ocean changes.

\section{ACKONWLEDGEMENTS}

The authors would like to thank S. El Khatabbi, C. Mac Loughlin, R. Arroyo and L. Custodio for helping in the collection of samples and Laboratorio de Genética Molecular
(CIBNOR) for technical assistance in analyzing samples. This research was funded by CONACYT-Proyecto Ciencia Básica (CB-2015-257524) Genomic landscape in the marine environment: patterns of adaptive diversity. The collection permit was provided by the Secretaría de Agricultura y Desarrollo Rural PPF/DGOPA/-010/19. PCG is a recipient of a CONACYT scholarship (782604).

\section{LITERATURE CITED}

Bernal, G., Ripa, P., Herguera, J.C. 2001. Variabilidad Oceanográfica Y Climática En El Bajo Golfo De California: Influencias Del Trópico Y Pacífico Norte Oceanographic and Climatic Variability in the Lower Gulf of California: Links With the Tropics and North Pacific. Ciencias Mar. 27: 595-617.

Brandl, S.J., Goatley, C.H.R., Bellwood, D.R., Tornabene, L. 2018. The hidden half: ecology and evolution of cryptobenthic fishes on coral reefs. Biol. Rev. 93: 1846-1873. doi:10.1111/ brv. 12423

Buckley, B.A., Hofmann, G.E. 2002. Thermal acclimation changes DNA-binding activity of heat shock factor 1 (HSF1) in the goby Gillichthys mirabilis: implications for plasticity in the heat-shock response in natural populations. J. Exp. Biol. 205: 3231-40.

Chomczynski, P., Sacchi, N. 1987. Single-step method of RNA isolation by acid guanidinium thiocyanate-phenolchloroform extraction. Anal. Biochem. 162: 156-159. doi:10.1006/abio.1987.9999

Culumber, Z.W., Shepard, D.B., Coleman, S.W., Rosenthal, G.G., Tobler, M. 2012. Physiological adaptation along environmental gradients and replicated hybrid zone structure in swordtails (Teleostei: Xiphophorus). J. Evol. Biol. 25: 1800-1814. doi:10.1111/j.1420-9101.2012.02562.x

Dietz, T.J. 1994. Acclimation of the threshold induction temperatures for 70-kDa and 90-kDa heat shock proteins in the fish Gillichthys mirabilis. J. Exp. Biol. 188: 333-8.

Evans, T.G., Hofmann, G.E. 2012. Defining the limits of physiological plasticity: how gene expression can assess and predict the consequences of ocean change. Philos. Trans. R. Soc. B Biol. Sci. 367: 1733-1745. doi:10.1098/rstb.2012.0019

Feder, M.E., Hofmann, G.E. 1999. Heat shock proteins, molecular chaperones, and the stress response: evolutionary and ecological physiology. Annu. Rev. Physiol. 61: 243-282.

Feidantsis, K., Antonopoulou, E., Lazou, A., Pörtner, H.O., Michaelidis, B. 2013. Seasonal variations of cellular stress response of the gilthead sea bream (Sparus aurata). J. Comp. Physiol. B 183: 625-639. doi:10.1007/s00360-012-0735-y

Guerriero, G., Bassem, S.M., Khalil, W.K.B., Temraz, T.A., Ciarcia, G., Gawad, F.K.A. 2018. Temperature changes and marine fish species (Epinephelus coioides and Sparus aurata): Role of oxidative stress biomarkers in toxicological food studies. Emirates J. Food Agric. 30: 205. doi:10.9755/ejfa.2018.v30. i3.1650

Gunderson, A.R., Armstrong, E.J., Stillman, J.H. 2016. Multiple Stressors in a Changing World: The Need for an Improved Perspective on Physiological Responses to the Dynamic Marine Environment. Ann. Rev. Mar. Sci. 8: 357-378. doi:10.1146/annurev-marine-122414-033953 
Habary, A., Johansen, J.L., Nay, T.J., Steffensen, J.F., Rummer, J.L. 2016. Adapt, move or die - how will tropical coral reef fishes cope with ocean warming? Glob. Chang. Biol. 23: 566-577. doi: $10.1111 / \mathrm{gcb} .13488$

Harborne, A.R. 2013. The ecology, behaviour and physiology of fishes on coral reef flats, and the potential impacts of climate change. J. Fish Biol. 83: 417-447. doi:10.1111/jfb.12203

Hassan, A., El Nahas, A.F., Mahmoud, S., Barakat, M.E., Ammar, A.Y. 2017. Thermal stress of ambient temperature modulate expression of stress and immune-related genes and DNA fragmentation in Nile tilapia (Oreochromis niloticus (Linnaeus, 1758)). Appl. Ecol. Environ. Res. 15: 1343-1354. doi:10.15666/aeer/1503_13431354

Heredia-Middleton, P., Brunelli, J., Drew, R.E., Thorgaard, G.H. 2008. Heat shock protein (HSP70) RNA expression differs among rainbow trout (Oncorhynchus mykiss) clonal lines. Comp. Biochem. Physiol. - B Biochem. Mol. Biol. 149: 552556. doi:10.1016/j.cbpb.2007.05.012

Hoey, A., Howells, E., Johansen, J., Hobbs, J.-P., Messmer, V., McCowan, D., Wilson, S., Pratchett, M. 2016. Recent Advances in Understanding the Effects of Climate Change on Coral Reefs. Diversity 8: 12. doi:10.3390/d8020012

Hofmann, G.E. 2005. Patterns of Hsp gene expression in ectothermic marine organisms on small to large biogeographic scales. Integr. Comp. Biol. 45: 247-255. doi:10.1093/icb/45.2.247

Illing, B., Rummer, J.L. 2017. Physiology can contribute to better understanding, management, and conservation of coral reef fishes. Conserv. Physiol. 5: 1-11. doi:10.1093/conphys/ cox005

Jesus, T.F., Inácio, Â., Coelho, M.M. 2013. Different levels of hsp70 and hsc70 mRNA expression in Iberian fish exposed to distinct river conditions. Genet. Mol. Biol. 36: 061-069. doi:10.1590/S1415-47572013000100009

Kwiatkowski, L., Gaylord, B., Hill, T., Hosfelt, J., Kroeker, K.J., Nebuchina, Y., Ninokawa, A., Russell, A.D., Rivest, E.B., Sesboüé, M., Caldeira, K. 2016. Nighttime dissolution in a temperate coastal ocean ecosystem increases under acidification. Nat. Publ. Gr. 1-9. doi:10.1038/srep22984

Levy, O., Kaniewska, P., Alon, S., Eisenberg, E., Karako-Lampert, S., Bay, L.K., Reef, R., Rodriguez-Lanetty, M., Miller, D.J., HoeghGuldberg, O. 2011. Complex Diel Cycles of Gene Expression in Coral-Algal Symbiosis. Science (80-.). 331: 175-175. doi:10.1126/science.1196419

Lewis, M., Götting, M., Anttila, K., Kanerva, M., Prokkola, J.M., Seppänen, E., Kolari, I., Nikinmaa, M. 2016. Different Relationship between hsp70 mRNA and hsp70 Levels in the Heat Shock Response of Two Salmonids with Dissimilar Temperature Preference. Front. Physiol. 7: 1-12. doi:10.3389/ fphys.2016.00511

Logan, C. A., Somero, G.N. 2011. Effects of thermal acclimation on transcriptional responses to acute heat stress in the eurythermal fish Gillichthys mirabilis (Cooper). Am. J. Physiol. Regul. Integr. Comp. Physiol. 300: R1373-R1383. doi:10.1152/ ajpregu.00689.2010

Lund, S.G., Caissie, D., Cunjak, R.A., Vijayan, M.M., Tufts, B.L. 2002. The effects of environmental heat stress on heat-shock mRNA and protein expression in Miramichi Atlantic salmon (Salmo salar) parr. Can. J. Fish. Aquat. Sci. 59: 1553-1562. doi:10.1139/f02-117
Ma, F., Liu, Z., Huang, J. Q., Kang, Y. J., Wang, J. F. 2019. Evaluation of reference genes for quantitative real-time PCR analysis of messenger RNAs and microRNAs in rainbow trout Oncorhynchus mykiss under heat stress. Journal of Fish Biology. 95(2): 540-554 doi:10.1111/jfb.13986

Madeira, D., Narciso, L., Cabral, H.N., Vinagre, C., Diniz, M.S. 2012. HSP70 production patterns in coastal and estuarine organisms facing increasing temperatures. J. Sea Res. 73: 137-147. doi:10.1016/j.seares.2012.07.003

Martínez-Flores, G. 2007. Caracterización de la temperatura superficial del mar y climatología de la Bahía de La Paz, B.C.S., México 21: 81-91.

Martínez-López, A., Cervantes-Duarte, R., Reyes-Salinas, A., Valdez-Holguín, J.E. 2001. Cambio estacional de clorofila a en la Bahía de La Paz, BCS, Mexico. Hidrobiológica. 11 (1): 45-52. ISSN 0188-8897

Munday, P.L., Donelson, J.M., Domingos, J.A. 2017. Potential for adaptation to climate change in a coral reef fish. Glob. Chang. Biol. 23: 307-317. doi:10.1111/gcb.13419

Nascimento, A.R., Silva, G.F., Gualberto, G.F., Almeida, F.L. 2016. Validation of reference genes for real-time quantitative PCR in tambaqui (Colossoma macropomum). Genetics and Molecular Research. 15 (4): gmr15049228. doi: 10.4238/ gmr15049228

Obeso-Nieblas, M., Shirasago, B., Sánchez-Velasco, L., GaviñoRodriguez, J.H. 2004. Hydrographic variability in Bahia De La Paz, B. C. S, Mexico, during the 1997-1998 El Niño. Deep Sea Res. Part II Top. Stud. Oceanogr. 51: 689-710. doi:10.1016/j. dsr2.2004.05.005

Oren, M., Tarrant, A.M., Alon, S., Simon-Blecher, N., Elbaz, I., Appelbaum, L., Levy, O. 2015. Profiling molecular and behavioral circadian rhythms in the non-symbiotic sea anemone Nematostella vectensis. Sci. Rep. 5: 11418. doi:10.1038/srep11418

Pfaffl, M.W. 2001. A new mathematical model for relative quantification in realtime RT-PCR. Nucleic Acids Res. 29: e45. doi: 10.1093/nar/29.9.e45.

Podrabsky, J.E. 2004. Changes in gene expression associated with acclimation to constant temperatures and fluctuating daily temperatures in an annual killifish Austrofundulus limnaeus. J. Exp. Biol. 207: 2237-2254. doi:10.1242/jeb.01016

Pollock, M.S., Clarke, L.M.J., Dubé, M.G. 2007. The effects of hypoxia on fishes: from ecological relevance to physiological effects. Environ. Rev. 15: 1-14. doi:10.1139/a06-006

Purohit, G. K., Mahanty, A., Mohanty, B. P., Mohanty, S. 2015. Evaluation of housekeeping genes as references for quantitative real-time PCR analysis of gene expression in the murrel Channa striatus under high-temperature stress. Fish Physiology and Biochemistry, 42(1): 125-135. doi:10.1007/ s10695-015-0123-0

Rummer, J.L., Couturier, C.S., Stecyk, J.A.W., Gardiner, N.M., Kinch, J.P., Nilsson, G.E., Munday, P.L. 2014. Life on the edge: thermal optima for aerobic scope of equatorial reef fishes are close to current day temperatures. Glob. Chang. Biol. 20: 1055-1066. doi:10.1111/gcb.12455

Silver, J.T., Noble, E.G. 2012. Regulation of survival gene hsp70. Cell Stress Chaperones 17: 1-9. doi:10.1007/s12192-0110290-6

Tine, M. 2017. Evidence of the Complexity of Gene Expression Analysis in Fish Wild Populations. Int. J. Genomics 2017: 1-14. doi:10.1155/2017/1258396 
Tomanek, L. 2010. Variation in the heat shock response and its implication for predicting the effect of global climate change on species' biogeographical distribution ranges and metabolic costs. J. Exp. Biol. 213: 971-979. doi:10.1242/ jeb.038034

Tunnah, L., Currie, S., MacCormack, T.J. 2017. Do prior diel thermal cycles influence the physiological response of Atlantic salmon (Salmo salar) to subsequent heat stress? Can. J. Fish. Aquat. Sci. 74: 127-139. doi:10.1139/cjfas-2016-0157

Untergasser, A., Cutcutache, I., Koressaar, T., Ye, J., Faircloth, B.C., Remm, M., Rozen, S.G. 2012. Primer3-new capabilities and interfaces. Nucleic Acids Res. 40, e115-e115. doi:10.1093/ nar/gks596

Vaquer-Sunyer, R., Duarte, C.M. 2008. Thresholds of hypoxia for marine biodiversity. Proc. Natl. Acad. Sci. 105: 15452-15457. doi:10.1073/pnas.0803833105
Veilleux, H.D., Ryu, T., Donelson, J.M., Ravasi, T., Munday, P.L. 2018. Molecular Response to Extreme Summer Temperatures Differs Between Two Genetically Differentiated Populations of a Coral Reef Fish. Front. Mar. Sci. 5: 1-12. doi:10.3389/ fmars.2018.00349

Vera, L.M., Negrini, P., Zagatti, C., Frigato, E., Sánchez-Vázquez, F.J., Bertolucci, C. 2013. Light and feeding entrainment of the molecular circadian clock in a marine teleost (Sparus aurata). Chronobiol. Int. 30: 649-61. doi:10.3109/07420528.2013.775 143

Yamashita, M., Yabu, T., Ojima, N. 2010. Stress Protein HSP70 in Fish. Aqua-BioScience Monogr. 3: 111-141. doi:10.5047/ absm.2010.00304.0111 